\title{
Effect of Nitrate, Two Oils and Their Combinations Added To Two Different Forage: Concentrate Ratios On Some Rumen Parameters and Protozoa Population.
}

Euloge O.A. OLOMONCHI ( $\square$ olomonchi@yahoo.fr)

Ondokuz Mayis University Faculty of Agriculture: Ondokuz Mayis Universitesi Ziraat Fakultesi https://orcid.org/0000-0002-0430-2052

Ali V. GARIPOĞLU

Ondokuz Mayis University Faculty of Agriculture: Ondokuz Mayis Universitesi Ziraat Fakultesi

\section{Research Article}

Keywords: Protozoa population, forage:concentrate, methane production, volatile fatty acids, nitrate, oils, ammonia.

Posted Date: October 28th, 2021

DOI: https://doi.org/10.21203/rs.3.rs-949456/v1

License: (1) This work is licensed under a Creative Commons Attribution 4.0 International License. Read Full License 


\section{Abstract}

This study aimed to determine the effects of nitrate, and two oils (0) (soybean and hazelnut oils) alone or in combination, on in vitro methane $\left(\mathrm{CH}_{4}\right)$ production, volatile fatty acid (VFA) and ammonia $\left(\mathrm{NH}_{3}\right)$ concentrations, $\mathrm{pH}$, and protozoa population. For that, $2 \times 2 \times 3$ factorial design with 2 two different forage:concentrate (F:C) ratios (40F:60C, and 60F:40C), 2 sources of nitrogen (sodium nitrate $\left(\mathrm{NO}_{3}^{-}\right.$: $45.94 \mathrm{~g} / \mathrm{kg} \mathrm{DM}$ ) or urea (16.45 g/kg DM for control group) and 2 oils (hazelnut oil (HO: $36.58 \mathrm{~g} / \mathrm{kg} \mathrm{DM}$ ) or soybean oil (SO: $36.58 \mathrm{~g} / \mathrm{kg}$ $\mathrm{DM})$ ). For every forage: concentrate $(\mathrm{F}: \mathrm{C})$ ratio, six (6) treatment groups were formulated: $\mathrm{F}: \mathrm{C}+\mathrm{Urea}, \mathrm{F}: \mathrm{C}+\mathrm{NO}^{-}{ }_{3}, \mathrm{~F}: \mathrm{C}+\mathrm{Urea}+\mathrm{HO}, \mathrm{F}: \mathrm{C}+$ Urea $+\mathrm{SO}, \mathrm{F}: \mathrm{C}+\mathrm{NO}_{3}^{-}+\mathrm{HO}, \mathrm{F}: \mathrm{C}+\mathrm{NO}_{3}^{-}{ }_{3}+\mathrm{SO}$. For every F:C ratio while $\mathrm{NO}_{3}^{-}(\mathrm{p}<0.01)$, oils $(\mathrm{p}<0.01)$, and $\mathrm{NO}^{-}{ }_{3}+$ oils $(\mathrm{SO}, \mathrm{HO})(\mathrm{p}<0.01)$ decreased $\mathrm{CH}_{4}$ content, protozoa population, ammonia $\left(\mathrm{NH}_{3}\right)$ concentration, acetic acid, total VFA, acetic acid: propionic acid ratio and pH, they increased butyric acid and propionic acid concentrations. Furthermore, $\mathrm{CH}_{4}$ production (12.44 vs $\left.9.09 \mathrm{ml}\right)$, ammonia (8.23 vs 7.37 $\mathrm{mmol} / \mathrm{l})$, propionic acid (19.14 vs $17.93 \mathrm{mmol} / \mathrm{l})$, butyric acid (15.50 vs $14.50 \mathrm{mmol} / \mathrm{l})$, total VFA ( $86.46 \mathrm{vs} 85.66 \mathrm{mmol} / \mathrm{l})$, protozoa population (32.16 vs $26.96 \times 10^{4} \mathrm{ml}$.) were high in early lactation period. In both lactation periods, $\mathrm{SO}$ and $\mathrm{NO}^{-}{ }_{3}+\mathrm{SO}$ decreased acetic acid concentration, protozoa population, and thus $\mathrm{CH}_{4}$ production.

\section{Introduction}

Methane $\left(\mathrm{CH}_{4}\right)$, a product of ruminal microbial fermentation, is a major contributor to global warming (IPCC, 2014). One of the main actors in $\mathrm{CH}_{4}$ production are ruminants. The amount of $\mathrm{CH}_{4}$ produced in the rumen is an indicator for estimating environmental impacts and energy costs in the animal production sector (Auffret et al., 2018). Archaea are responsible for microbial fermentation in anaerobic rumen environment (Yang et al., 2017). For this reason, the decrease of the population of archaea is related to $\mathrm{CH}_{4}$ mitigation in the rumen.

Usingnitrate as a feed additive in ruminant nutrition, is one of best strategies to reduce enteric $\mathrm{CH}_{4}$ emissions (Hristov et al., 2013). In the rumen, nitrate uses free hydrogen for the production of ammonia to the detriment of $\mathrm{CH}_{4}$ production. Thus, $\mathrm{CH}_{4}$ production decreases (van Zijderveld et al., 2011). Some studies show a decrease of enteric methanogenesis, microbial growth (Ungerfeld and Kohn, 2006), inhibition of total gas volume and $\mathrm{CH}_{4}$ emission (Guyader et al., 2016), an increase of ammonia $\left(\mathrm{NH}_{3}\right)$ concentration in the rumen (Sharifi et al., 2018) due to the use of nitrate in the ration. Another $\mathrm{CH}_{4}$ mitigation way is the use of lipids in the diet. In recent years, the use of lipids as a feed additive has been adopted as an alternative to mitigate $\mathrm{CH}_{4}$ in the rumen (Boadi et al., 2004; Martin et al., 2010). Some researchers have reported that the alfalfa plant (because of its high nutritional value) positively affects the levels of digestion and absorption of nutrients, leading to increased productivity levels in ruminants (Paterson et al., 1982; Hunt et al., 1985; Brandt and Klopfenstein, 1986a; b; Leng 1990; Ørskov et al., 1999). On the other hand, some studies reported a low fiber content for alfalfa (28-30\%) (Muir et al., 2003; Koukoura et al., 2009; Kuchenmeister et al., 2013; KanthaRaju et al., 2018). It has been found that the rations used in the present study have low fiber content in both forage:concentrate ratios. In addition, nutritional contents of rations used in both forage:concentrate ratios in the present study are similar to some studies (Sharifi et al., 2018; Alvarez- Hess et al., 2019; Villar et al., 2019). Lipids plays an important role due to their effect on the protozoa population. In fact, protozoa stimulate hydrogen production and so methanogenesis (Guyader et al., 2015). Lloyd et al. (1989), reported rumen protozoa to have a high oxygen-scavenging ability. Thanks to these ability protozoa lead to decrease in production of $\mathrm{H}_{2}$ and methane in rumen. Here, oils rich in unsaturated fatty acids (monounsaturated fatty acids (MUFA) or polyunsaturated fatty acids (PUFA)) reduce $\mathrm{CH}_{4}$ emissions (McGinn et al., 2004; Beauchemin et al., 2007). Some studies have shown the complementary mitigation effect of lipids and $\mathrm{NO}_{3}^{-}$on $\mathrm{CH}_{4}$ production in dry cows (Guyader et al., 2015) and dairy cows (Guyader et al., 2016). The aim of our study is to determine the combined effect of $\mathrm{NO}_{3}^{-}$and oils (Soybean (SO) and Hazelnut (HO) oils) addition in Medicago sativa-based rations on $\mathrm{CH}_{4}$ production and some rumen parameters $\left(\mathrm{pH}, \mathrm{NH}_{3}\right.$, protozoa numbers and volatile fatty acids (VFA)).

\section{Materials And Methods}

\subsection{Rations and experimental design}

This study was conducted in the Laboratory of Animal Nutrition, Department of Animal Science, Faculty of Agriculture, Ondokuz Mayıs University, Samsun, Turkey. Our study was carried out according to $2 \times 2 \times 3$ factorial design with 2 forage:concentrate ratios (40F:60C and 60F:40C), 2 sources of nitrogen (sodium nitrate $\left(\mathrm{NO}_{3}^{-}: 45.94 \mathrm{~g} / \mathrm{kg} \mathrm{DM}\right.$ ) or urea (16.45)) and 2 oils (Hazelnut oil (HO: $\left.36.58 \mathrm{~g} / \mathrm{kg} \mathrm{DM}\right)$ or Soybean oil (SO: $36.58 \mathrm{~g} / \mathrm{kg} \mathrm{DM}$ )). Isonitrogenic rations were used in our study (urea was used in the control group in order to balance the protein content of rations). For every forage:concentrate ratio, six (6) treatment groups were formulated: $\mathrm{F}: \mathrm{C}+\mathrm{Urea}, \mathrm{F}: \mathrm{C}+\mathrm{NO}^{-}{ }_{3}, \mathrm{~F}: \mathrm{C}+\mathrm{Urea}$ 
$+\mathrm{HO}, \mathrm{F}: \mathrm{C}+\mathrm{Urea}+\mathrm{SO}, \mathrm{F}: \mathrm{C}+\mathrm{NO}^{-}{ }_{3}+\mathrm{HO}, \mathrm{F}: \mathrm{C}+\mathrm{NO}^{-}{ }_{3}+\mathrm{SO}$. Treatment groups and rations content were shown in Table 1. $\mathrm{N}$ sources (sodium nitrate and urea) and oils (hazelnut oil and soybean oil) were purchased from market. Medicago sativa was obtained from research farm of Ondokuz Mayis University in Bafra district. Rumen fluid used in this study was taken from a private slaughterhouse operating in Atakum district of Samsun. Chemical composition of rations used are given in Table 2. 
Table 1

Treatment groups and rations content (g/kg DM)

\begin{tabular}{|c|c|c|c|c|c|c|c|c|c|c|c|c|}
\hline \multirow[t]{4}{*}{ Ingredients } & \multicolumn{12}{|c|}{ Treatment (g.kg-1 DM) } \\
\hline & \multicolumn{6}{|c|}{ 40F:60C } & \multicolumn{6}{|c|}{$60 F: 40 C$} \\
\hline & \multicolumn{3}{|l|}{ Control } & \multicolumn{3}{|l|}{$\mathrm{NO}_{3}^{-}$} & \multicolumn{3}{|c|}{ Control } & \multicolumn{3}{|l|}{$\mathrm{NO}_{3}^{-}$} \\
\hline & $\begin{array}{l}\text { Oil- } \\
\text { free }\end{array}$ & $\mathrm{HO}$ & so & $\begin{array}{l}\text { Oil- } \\
\text { free }\end{array}$ & $\mathrm{HO}$ & so & $\begin{array}{l}\text { Oil- } \\
\text { free }\end{array}$ & $\mathrm{HO}$ & so & $\begin{array}{l}\text { Oil- } \\
\text { free }\end{array}$ & $\mathrm{HO}$ & so \\
\hline $\begin{array}{l}\text { Medicago } \\
\text { sativa }\end{array}$ & 400 & 400 & 400 & 400 & 400 & 400 & 600 & 600 & 600 & 600 & 600 & 600 \\
\hline Wheat bran & 140.14 & 140.14 & 140.14 & 140.14 & 140.14 & 140.14 & 128 & 128 & 128 & 128 & 128 & 128 \\
\hline $\begin{array}{l}\text { Sunflower } \\
\text { Seed Meal } \\
(\text { SSM) }(28 \%)\end{array}$ & - & - & - & - & - & - & 62.08 & 62.08 & 62.08 & 62.08 & 62.08 & 62.08 \\
\hline D.D.G.S(Corn) & 78.6 & 78.6 & 78.6 & 78.6 & 78.6 & 78.6 & 48 & 48 & 48 & 48 & 48 & 48 \\
\hline SSM (\%36) & 185.29 & 185.29 & 185.29 & 185.29 & 185.29 & 185.29 & 43.06 & 43.06 & 43.06 & 43.06 & 43.06 & 43.06 \\
\hline Corn extract & 60 & 60 & 60 & 60 & 60 & 60 & 30.45 & 30.45 & 30.45 & 30.45 & 30.45 & 30.45 \\
\hline $\begin{array}{l}\text { Cracked } \\
\text { wheat }\end{array}$ & 42 & 42 & 42 & 42 & 42 & 42 & 28 & 28 & 28 & 28 & 28 & 28 \\
\hline $\begin{array}{l}\text { SSM sieved } \\
\text { wastes }\end{array}$ & 18 & 24 & 18 & 24 & 18 & 24 & 16 & 16 & 16 & 16 & 16 & 16 \\
\hline Molasses & 23.4 & 23.4 & 23.4 & 23.4 & 23.4 & 23.4 & 15.6 & 15.6 & 15.6 & 15.6 & 15.6 & 15.6 \\
\hline Corn & 13.2 & 13.2 & 13.2 & 13.2 & 13.2 & 13.2 & - & - & - & - & - & - \\
\hline $\begin{array}{l}\text { Sesame } \\
\text { sieved } \\
\text { wastes }\end{array}$ & 9 & 9 & 9 & 9 & 9 & 9 & 8 & 8 & 8 & 8 & 8 & 8 \\
\hline Sesame bran & 9 & 9 & 9 & 9 & 9 & 9 & 8 & 8 & 8 & 8 & 8 & 8 \\
\hline Potassium & 1.06 & 1.06 & 1.06 & 1.06 & 1.06 & 1.06 & 0.41 & 0.41 & 0.41 & 0.41 & 0.41 & 0.41 \\
\hline Methionine & 0.43 & 0.43 & 0.43 & 0.43 & 0.43 & 0.43 & 1.03 & 1.03 & 1.03 & 1.03 & 1.03 & 1.03 \\
\hline Lysine & 0.74 & 0.74 & 0.74 & 0.74 & 0.74 & 0.74 & 0.37 & 0.37 & 0.37 & 0.37 & 0.37 & 0.37 \\
\hline Calcium & 1.04 & 1.04 & 1.04 & 1.04 & 1.04 & 1.04 & 1.01 & 1.01 & 1.01 & 1.01 & 1.01 & 1.01 \\
\hline Phosphorus & 0.80 & 0.80 & 0.80 & 0.80 & 0.80 & 0.80 & 0.83 & 0.83 & 0.83 & 0.83 & 0.83 & 0.83 \\
\hline Sugar & 5.6 & 5.6 & 5.6 & 5.6 & 5.6 & 5.6 & 5.02 & 5.02 & 5.02 & 5.02 & 5.02 & 5.02 \\
\hline Starch & 17 & 17 & 17 & 17 & 17 & 17 & 16.03 & 16.03 & 16.03 & 16.03 & 16.03 & 16.03 \\
\hline $\begin{array}{l}\text { Bypass } \\
\text { starch }\end{array}$ & 7.09 & 7.09 & 7.09 & 7.09 & 7.09 & 7.09 & 8.05 & 8.05 & 8.05 & 8.05 & 8.05 & 8.05 \\
\hline Halzenut oil & - & 36.58 & - & - & 36.58 & - & - & 36.58 & - & - & 36.58 & - \\
\hline Soybean oil & - & - & 36.58 & - & - & 36.58 & - & - & 36.58 & - & - & 36.58 \\
\hline $\begin{array}{l}\text { Sodium } \\
\text { nitrate }\end{array}$ & - & - & - & 45.94 & 45.94 & 45.94 & - & - & - & 45.65 & 45.65 & 45.65 \\
\hline Urea & 16.45 & 16.45 & 16.45 & - & - & - & 16.34 & 16.34 & 16.34 & - & - & - \\
\hline UFL & 83.54 & 83.54 & 83.54 & 83.54 & 83.54 & 83.54 & 81.02 & 81.02 & 81.02 & 81.02 & 81.02 & 81.02 \\
\hline $\begin{array}{l}\text { Vitamin bovine } \\
0 \mathrm{~g} / \mathrm{kg} \text { DM), M } \\
\text { small intestine } \\
\text { UFV: Net energ }\end{array}$ & $\begin{array}{l}+(0.6 ; 0 \\
\text { nesium } \\
\text { DIN }=\text { tr } \\
\text { or meat }\end{array}$ & $\begin{array}{l}\mathrm{y} / \mathrm{kg} \mathrm{DM} \\
\text { ide }(0.6 ; \\
\text { protein a }\end{array}$ & $\begin{array}{l}\text { marble p } \\
4 \mathrm{~g} / \mathrm{kg} \mathrm{D} \\
\text { sorbable }\end{array}$ & $\begin{array}{l}\text { wder (12 } \\
\text { ), Yeast } \\
\text { the sm }\end{array}$ & $\begin{array}{l}\mathrm{g} / \mathrm{kg} \mathrm{D} \\
6 ; 0.4 \mathrm{~g} \\
\text { intestin }\end{array}$ & $\begin{array}{l}\text { Salt (3 } \\
\text { DM DM }) 1 \\
\text { when de }\end{array}$ & $\begin{array}{l}\mathrm{g} / \mathrm{kg} \text { [ } \\
\text { Metal } \\
\text { adable }\end{array}$ & $\begin{array}{l}\text { Niacir } \\
\text { c energ } \\
\text { s limiti }\end{array}$ & $\begin{array}{l}0 \text { (0.6 } \\
\text { DIE: t } \\
\text { nicrol }\end{array}$ & $\begin{array}{l}4 \mathrm{~g} / \mathrm{kg} \\
\text { protein } \\
\text { UFL: } \mathrm{N}\end{array}$ & $\begin{array}{l}\text { Nova } \\
\text { orbab } \\
\text { ergy }\end{array}$ & $\begin{array}{l}\text { n (0.6; } \\
\text { in the } \\
\text { m ilk, }\end{array}$ \\
\hline
\end{tabular}




\begin{tabular}{|c|c|c|c|c|c|c|c|c|c|c|c|c|}
\hline \multirow[t]{4}{*}{ Ingredients } & \multicolumn{12}{|c|}{ Treatment $\left(\mathbf{g} \cdot \mathrm{kg}^{-1} \mathrm{DM}\right)$} \\
\hline & \multicolumn{6}{|c|}{$40 \mathrm{~F}: 60 \mathrm{C}$} & \multicolumn{6}{|c|}{$60 \mathrm{~F}: 40 \mathrm{C}$} \\
\hline & \multicolumn{3}{|l|}{ Control } & \multicolumn{3}{|l|}{$\mathrm{NO}_{3}^{-}$} & \multicolumn{3}{|l|}{ Control } & \multicolumn{3}{|l|}{$\mathrm{NO}_{3}^{-}$} \\
\hline & $\begin{array}{l}\text { Oil- } \\
\text { free }\end{array}$ & $\mathrm{HO}$ & so & $\begin{array}{l}\text { Oil- } \\
\text { free }\end{array}$ & $\mathrm{HO}$ & so & $\begin{array}{l}\text { Oil- } \\
\text { free }\end{array}$ & $\mathrm{HO}$ & so & $\begin{array}{l}\text { Oil- } \\
\text { free }\end{array}$ & $\mathrm{HO}$ & so \\
\hline UFV & 79 & 79 & 79 & 79 & 79 & 79 & 76.12 & 76.12 & 76.12 & 76.12 & 76.12 & 76.12 \\
\hline $\begin{array}{l}\text { PDIN (g/kg } \\
\text { DM) }\end{array}$ & 147.35 & 147.35 & 147.35 & 147.35 & 147.35 & 147.35 & 132.7 & 132.7 & 132.7 & 132.7 & 132.7 & 132.7 \\
\hline $\begin{array}{l}\text { PDIE (g/kg } \\
\text { DM) }\end{array}$ & 120.96 & 120.96 & 120.96 & 120.96 & 120.96 & 120.96 & 101.25 & 101.2 & 101.25 & 101.25 & 101.2 & 101.2 \\
\hline $\begin{array}{l}\text { ME (kcal. } \\
\left.\mathrm{Kg}^{-1} \mathrm{DM}\right)\end{array}$ & 2550 & 2550 & 2550 & 2550 & 2550 & 2550 & 2500 & 2500 & 2500 & 2500 & 2500 & 2500 \\
\hline \multicolumn{13}{|c|}{$\begin{array}{l}\text { Vitamin bovine } \mathrm{A}^{+}(0.6 ; 0.4 \mathrm{~g} / \mathrm{kg} \mathrm{DM}) \text {, marble powder }(12 ; 8 \mathrm{~g} / \mathrm{kg} \mathrm{DM}) \text {, Salt }(3 ; 2 \mathrm{~g} / \mathrm{kg} \mathrm{DM}) \text {, Niacin } 200(0.6 ; 0.4 \mathrm{~g} / \mathrm{kg} \mathrm{DM}) \text {, Novatan }(0.6 \text {; } \\
0 \mathrm{~g} / \mathrm{kg} \text { DM), Magnesium oxide }(0.6 ; 0.4 \mathrm{~g} / \mathrm{kg} \text { DM), Yeast (0.6; } 0.4 \mathrm{~g} / \mathrm{kg} \text { DM), ME: Metabolic energy, PDIE: true protein absorbable in the } \\
\text { small intestine, PDIN = true protein absorbable in the small intestine when degradable N is limiting microbial, UFL: Net energy form ilk, } \\
\text { UFV: Net energy for meat }\end{array}$} \\
\hline
\end{tabular}

Table 2

Nutrient content of rations with different forage:concentrate ratios supplemented with $\mathrm{NO}_{3}^{-}, \mathrm{O}(\mathrm{HO}$ amd SO$)$, and $\mathrm{NO}_{3}^{-}+0$.

\begin{tabular}{|c|c|c|c|c|c|c|c|c|c|c|c|c|}
\hline \multirow{3}{*}{$\begin{array}{l}\text { Nutrients } \\
\text { (g/kg DM) }\end{array}$} & \multicolumn{6}{|c|}{$40 \mathrm{~F}: 60 \mathrm{C}$} & \multicolumn{6}{|c|}{$60 \mathrm{~F}: 40 \mathrm{C}$} \\
\hline & \multicolumn{3}{|c|}{ Control } & \multicolumn{3}{|l|}{$\mathrm{NO}^{-}{ }_{3}$} & \multicolumn{3}{|c|}{ Control } & \multicolumn{3}{|l|}{$\mathrm{NO}_{3}^{-}$} \\
\hline & $\begin{array}{l}\text { Oil- } \\
\text { free }\end{array}$ & so & $\mathrm{HO}$ & $\begin{array}{l}\text { Oil- } \\
\text { free }\end{array}$ & so & $\mathrm{HO}$ & $\begin{array}{l}\text { Oil- } \\
\text { free }\end{array}$ & so & $\mathrm{HO}$ & $\begin{array}{l}\text { Oil- } \\
\text { free }\end{array}$ & so & $\mathrm{HO}$ \\
\hline Ash & 6.21 & 6.33 & 6.62 & 6.20 & 6.85 & 6.90 & 8.81 & 9.05 & 9.65 & 8.91 & 9.54 & 9.75 \\
\hline NDF & 33.27 & 33.80 & 33.27 & 33.90 & 33.99 & 33.90 & 34.25 & 34.74 & 34.88 & 34.52 & 34.88 & 34.78 \\
\hline$A D F$ & 20.18 & 20.94 & 20.33 & 20.35 & 20.57 & 20.77 & 21.00 & 21.75 & 21.29 & 21.70 & 21.81 & 21.60 \\
\hline $\mathrm{EE}$ & 3.70 & 8.27 & 8.85 & 3.60 & 9.41 & 9.35 & 3.47 & 9.26 & 9.52 & 3.68 & 9.23 & 9.45 \\
\hline $\mathrm{CP}$ & 23.55 & 24.20 & 24.05 & 23.50 & 24.32 & 24.03 & 23.75 & 24.10 & 24.01 & 23.67 & 24.46 & 24.54 \\
\hline $\mathrm{CF}$ & 24.85 & 23.12 & 23.00 & 24.60 & 23.12 & 23.63 & 24.32 & 22.38 & 22.46 & 24.10 & 21.86 & 21.33 \\
\hline$A D L$ & 7.63 & 7.90 & 8.10 & 7.55 & 7.79 & 7.74 & 8.95 & 8.25 & 8.50 & 9.02 & 8.60 & 8.75 \\
\hline HCEL & 13.09 & 12.86 & 12.94 & 13.55 & 13.42 & 13.13 & 13.25 & 12.99 & 13.59 & 12.82 & 13.07 & 13.18 \\
\hline CEL & 12.56 & 13.04 & 12.23 & 12.80 & 12.78 & 13.03 & 12.05 & 13.50 & 12.79 & 12.68 & 13.21 & 12.85 \\
\hline $\mathrm{OM}$ & 84.23 & 84.00 & 83.77 & 84.50 & 83.80 & 83.56 & 83.96 & 83.90 & 83.36 & 83.05 & 82.96 & 82.68 \\
\hline NFE & 32.13 & 28.41 & 27.90 & 32.80 & 26.95 & 26.55 & 32.42 & 28.06 & 27.37 & 31.60 & 27.41 & 27.30 \\
\hline NFC & 46.36 & 40.26 & 40.70 & 46.35 & 38.85 & 38.95 & 42.97 & 35.84 & 35.53 & 42.04 & 34.96 & 34.66 \\
\hline CT (g/kg DM) & 3.6 & 3.6 & 3.6 & 3.6 & 3.6 & 3.6 & 5.4 & 5.4 & 5.4 & 5.4 & 5.4 & 5.4 \\
\hline $\begin{array}{l}\text { Saponin (g/kg } \\
\text { DM) }\end{array}$ & 4.28 & 4.28 & 4.28 & 4.28 & 4.28 & 4.28 & 6.42 & 6.42 & 6.42 & 6.42 & 6.42 & 6.42 \\
\hline $\begin{array}{l}\text { NDF: Neutral De } \\
\text { HCEL: Hemicell } \\
\text { Tannins. }\end{array}$ & ${ }_{F}$ & r & Dator & ribo & 5 & the & Drot & CF: Cru & a & . & In & gnin, \\
\hline
\end{tabular}

\subsection{Determination of $\mathrm{CH}_{4}$ production}


Infrared $\mathrm{CH}_{4}$ analyzer (Sensor Europe $\mathrm{GmbH}$, Erkrath, Germany model) was used to determine the $\mathrm{CH}_{4}$ production in the rations used in present study (Goel et al., 2008). After 24 hours, the gas accumulated in the injectors was taken to the $\mathrm{CH}_{4}$ analyzer by means of a special tube (using plastic injectors) and $\mathrm{CH}_{4}$ production (ml) was determined as a percentage of total gas

$\mathrm{CH}_{4}$ production $(\mathrm{ml})=$ Total gas production $(\mathrm{ml}) \times \% \mathrm{CH}_{4}$

\subsection{Determination of $\mathrm{NH}_{3}$ concentration in the rumen fluid.}

For the determination of $\mathrm{NH}_{3}$ concentration, $5 \mathrm{ml}$ of rumen fluid was taken from the syringes after 48 hours. As in the protein analyses, a distillation was performed. Then the titration was done and the volume of $\mathrm{HCl}(0.1)$ was noted. Due to following formula, the amount of $\mathrm{NH}_{3}$ was determined.

$\mathrm{NH}_{3}(\mathrm{mg} / \mathrm{dl}$ rumen fluid $)=0.1 \times 14 \times 1.22(\mathrm{~A}-\mathrm{B}) \times 20$

A: Volume of $\mathrm{HCl}$ titration solution spent in titration for the sample $(\mathrm{ml})$.

B: Volume of $\mathrm{HCl}$ titration solution spent in titration for the witness $(\mathrm{ml})$.

0.1: Normality of $\mathrm{HCl}$ titration solution.

14: Molar masses of nitrogen.

\section{4. $\mathrm{pH}$ and VFA analysis in rumen fluid}

In our study, $5 \mathrm{ml}$ of rumen fluid was added to 2 wheaton flasks before incubation and 4 drops of $\mathrm{H}_{2} \mathrm{SO}_{4}$ were added to determine the content of VFA in the rumen fluid to be used in the study. The rumen fluids thus prepared were kept at room temperature until the analyzes were performed. The rumen fluid taken at 48th hour was subjected to the same treatment. The $\mathrm{pH}$ of the rumen liquid used in the experiment was determined by digital pH meter (HANNA INSTRUMENTS 1332 model pH meter) as soon as it was brought to the laboratory. Rumen fluid taken at 48th hour was subjected to the same treatment. VFA content of the ruminal fluid (Obtain after 48th hour of incubation) was made using the procedure described by Wiedmeier et al. (1987) and using gas chromatography (Agilent Tech. 6890N GC, Stabilwax-DA, $30 \mathrm{~m}, 0.25 \mathrm{~mm}$ ID, $0.25 \mu \mathrm{m}$ df. Max. Sıcaklık: $260^{\circ} \mathrm{C}$. Cat. 11023) at the University of Uludağ, Faculty of Agriculture, Department of Animal Sciences. Four drops of sulfuric acid were added to about $5 \mathrm{ml}$ of ruminal liquid fluid and the mixture was maintained at $-20^{\circ} \mathrm{C}$ and centrifuged at $10000 \mathrm{rpm}$ at $+4^{\circ} \mathrm{C}$.

\subsection{Determination of Protozoa Population}

After the mixing $0.6 \mathrm{~g}$ methyl green, $8 \mathrm{~g}$ sodium chloride $(\mathrm{NaCl})$ and $100 \mathrm{ml} 37 \%$ formaldehyde solution for staining the protozoa, the volume was increased to $1000 \mathrm{ml}$ with distilled water. One mililiter of rumen inoculum from the fermenter was mixed with 1 ml of methylgreen-formalin solution (MFS). The protozoa number was carried out with the object slide of a light microscope and Fuchs-Rosenthal counting chamber (depth:0.2 mm, small square area: $0.0625 \mathrm{~mm}^{2}$ ) (Ranilla et al., 1997). This mixture (Rumen fluid + MFS) was kept at $-20^{\circ} \mathrm{C}$ until analysis time. Subsequently, the samples taken from this mixture and shaken were placed on a Fuchs-Rosenthal slide $(16 \times 16$ squared. $0.0625 \mathrm{~mm} \sim$ area). Calculation is made with the formula given below:

\section{Number of cells in $\mathrm{cm}^{3}(\mathrm{ml})=1000 \times \frac{\text { Number of cells counted }}{\text { Total frames counted } \mathrm{x} \text { Dilution } \mathrm{x} \text { Volume }}$}

\subsection{Statistical analysis}

Data obtained as a result of the research (in vitro $\mathrm{CH}_{4}$ production, $\mathrm{NH}_{3}$ concentration, volatile fatty acids (VFA), $\mathrm{pH}$, and protozoa population) were checked for the necessary assumptions (such as normality and homogeneity of variances) and then analyzed in a randomized plot according to factorial experiment. The following model was used in the study.

$Y i j k l=\mu+a_{i}+\beta_{j}+\lambda_{k}+(a \beta) i j+(\beta \lambda)_{j k}+(a \lambda)_{i k}+(a \beta \lambda)_{i j k}+e_{i j k l}$

Where $\mathrm{Y}_{\mathrm{ijk}} \mathrm{i}^{\mathrm{i}}$ th application subject to $\mathrm{j}^{\text {th }}$ feed variety $\left(\mathrm{CH}_{4}\right.$ production, etc.) $\mathrm{k}^{\text {th }}$ observation value of the sample (gas production, etc.).

$\mu$ : mean population, 
$\mathrm{a}_{\mathrm{i}}$ : Effect of $\mathrm{i}^{\text {th }}$ ration

$\beta \mathrm{j}$ : Effect of the $\mathrm{j}^{\text {th }}$ additive

$\lambda$ : Effect of the $k^{\text {th }}$ oil addition

$(a \beta)_{i j}$ : Interaction of $\mathrm{i}^{\text {th }}$ ration and $\mathrm{j}^{\text {th }}$ additive effect

$(\beta \lambda)_{j \mathrm{k}}$ : Effect of interaction between $\mathrm{j}^{\text {th }}$ inci additive with $\mathrm{k}^{\text {th }}$ vegetable oil type

$(\mathrm{a} \lambda)_{\mathrm{ik}}$ : Effect of interaction between $\mathrm{i}^{\text {th }}$ ration with $\mathrm{k}^{\text {th }}$ vegetable oil type

$(\mathrm{a} \beta \lambda)_{\mathrm{ijk}}$ : Effect of interaction between $\mathrm{i}^{\text {th }}$ ration, $\mathrm{j}^{\text {th }}$ additive with $\mathrm{k}^{\text {th }}$ vegetable oil type

eijk: shows a random error.

Duncan Multiple Comparison test was used to compare the means if the differences between the applications or feed types were statistically significant. SPSS 22.0 statistical package program licensed by Ondokuz Mayıs University was used for statistical analysis.

\section{Results}

\subsection{Methane $\left(\mathrm{CH}_{4}\right)$ production}

In current study, $F: C$ ratio $(p=0.002)$, feed additive $(F A)(p<0.001)$, oils addition $(0)(p<0.001), F: C$ ratio $\times F A$ interaction $(p<0.001), F A \times 0$ interaction ( $p=0.007), \mathrm{F}: \mathrm{C}$ ratio $\times \mathrm{O}$ interaction $(\mathrm{p}<0.005)$, and $\mathrm{F}: \mathrm{C}$ ratio $\times \mathrm{FA} \times \mathrm{O}$ interaction $(\mathrm{p}=0.004)$ were found to affect $\mathrm{CH}_{4}$ production (Table 3). After 24 hours of fermentation, the high-concentrate (40F:60C) content rations led to higher $\mathrm{CH}_{4}$ productions. In $40 \mathrm{~F}: 60 \mathrm{C}$ and 60F:40C, $\mathrm{NO}_{3}^{-}$supplementation (compared to urea supplementation) and $\mathrm{NO}^{-}{ }_{3}+0$ supplementation (compared to urea +0 supplementation) decreased $\mathrm{CH}_{4}$ production. This combined effect of $\mathrm{NO}_{3}^{-}+$oils supplementation on $\mathrm{CH}_{4}$ production was more evident with a high forage content (60F:40C) compared to high concentrate content (40F:60C). However, in 40F:60C and 60F:40C, SO supplementation led to lower $\mathrm{CH}_{4}$ production compared to $\mathrm{HO}$ supplementation). 
Table 3

Effects of $\mathrm{NO}_{3}^{-}, \mathrm{O}(\mathrm{HO}$ and $\mathrm{SO})$, and $\mathrm{NO}_{3}^{-}+\mathrm{O}$ supplemented to different forage:concentrate ratios on rumen fermentation properties.

\begin{tabular}{|c|c|c|c|c|c|c|c|c|c|c|c|}
\hline \multirow{2}{*}{$\begin{array}{l}\text { Forage: } \\
\text { Concentrate }\end{array}$} & \multirow{2}{*}{$\begin{array}{l}\text { Feed } \\
\text { additive }\end{array}$} & \multirow[t]{2}{*}{ Oils } & \multirow[t]{2}{*}{$\mathrm{CH}_{4}$} & \multirow[t]{2}{*}{$\mathrm{NH}_{3}$} & \multicolumn{4}{|l|}{ VFA } & \multirow[t]{2}{*}{ AA:PA } & \multirow[t]{2}{*}{ PP } & \multirow[t]{2}{*}{$\mathrm{pH}$} \\
\hline & & & & & AA & PA & BA & TVFA & & & \\
\hline \multirow[t]{6}{*}{$40: 60$} & Control & $\begin{array}{l}\text { Oil- } \\
\text { free }\end{array}$ & $13.29^{a}$ & $9.20^{\mathrm{a}}$ & $49.57^{b}$ & $17.47^{d}$ & $15.51^{\mathrm{bc}}$ & $89.11^{a}$ & $2.84^{b}$ & $36.19^{a}$ & $6.12^{\mathrm{bc}}$ \\
\hline & & so & $11.05^{c}$ & $8.33^{b}$ & $46.04^{d}$ & $19.19^{b}$ & $14.53^{\text {def }}$ & $85.65^{\text {de }}$ & $2.40^{f g}$ & $29.25^{\mathrm{e}}$ & $5.95^{\mathrm{ef}}$ \\
\hline & & $\mathrm{HO}$ & $12.34^{b}$ & $8.98^{a}$ & $48.44^{\mathrm{bc}}$ & $18.58^{c}$ & $14.68^{\mathrm{de}}$ & $87.63^{b c}$ & $2.61^{c}$ & $32.69^{c}$ & $5.99^{\mathrm{def}}$ \\
\hline & $\mathrm{NO}_{3}^{-}$ & $\begin{array}{l}\text { Oil- } \\
\text { free }\end{array}$ & $11.94^{b}$ & $8.35^{b}$ & $47.29^{c d}$ & $19.21^{b}$ & $16.89^{a}$ & $87.14^{\mathrm{bcd}}$ & $2.46^{\text {def }}$ & $35.06^{b}$ & $6.08^{c}$ \\
\hline & & so & $7.18^{g}$ & $6.60^{f}$ & $43.24^{\mathrm{e}}$ & $20.84^{a}$ & $15.62^{b c}$ & $83.37^{f}$ & $2.07^{\mathrm{i}}$ & $27.69^{g}$ & $5.94^{f}$ \\
\hline & & $\mathrm{HO}$ & $8.62^{e}$ & $7.93^{c}$ & $46.55^{d}$ & $19.57^{b}$ & $15.74^{b}$ & $85.70^{\mathrm{de}}$ & $2.38^{g}$ & $32.06^{d}$ & $5.98^{\text {de }}$ \\
\hline \multirow[t]{6}{*}{$60: 40$} & Control & $\begin{array}{l}\text { Oil- } \\
\text { free }\end{array}$ & $12.27^{\mathrm{b}}$ & $8.34^{b}$ & $52.49^{a}$ & $16.77^{\mathrm{e}}$ & $13.95^{\mathrm{fg}}$ & $88.51^{a b}$ & $3.13^{a}$ & $28.31^{f}$ & $6.25^{a}$ \\
\hline & & so & $7.29^{g}$ & $7.28^{d}$ & $46.86^{d}$ & $18.55^{c}$ & $13.82^{\mathrm{g}}$ & $84.39^{\mathrm{ef}}$ & $2.53^{\mathrm{cd}}$ & $26.81^{h}$ & $6.00^{d}$ \\
\hline & & $\mathrm{HO}$ & $9.15^{\mathrm{e}}$ & $7.96^{c}$ & $49.36^{b}$ & $17.31^{\mathrm{de}}$ & $14.07^{f g}$ & $86.35^{\mathrm{cd}}$ & $2.85^{b}$ & $27.19 \mathrm{~g}$ & $6.08^{c}$ \\
\hline & $\mathrm{NO}_{3}^{-}$ & $\begin{array}{l}\text { Oil- } \\
\text { free }\end{array}$ & $9.82^{d}$ & $7.37^{d}$ & $51.19^{a b}$ & $16.80^{\mathrm{e}}$ & $15.70^{b}$ & $89.93^{a}$ & $3.04^{\mathrm{ab}}$ & $28.06^{f}$ & $6.16^{b}$ \\
\hline & & so & $7.35^{f}$ & $6.37^{f}$ & $43.85^{e}$ & $19.66^{b}$ & $14.41^{\mathrm{efg}}$ & $81.78^{g}$ & $2.23^{h}$ & $25.36^{j}$ & $5.99^{\mathrm{de}}$ \\
\hline & & $\mathrm{HO}$ & $8.68^{c}$ & $6.87^{\mathrm{e}}$ & $45.97^{d}$ & $18.47^{c}$ & $15.04^{\mathrm{cd}}$ & $83.01^{\mathrm{fg}}$ & $2.49^{\mathrm{de}}$ & $26.06^{i}$ & $6.08^{c}$ \\
\hline \multicolumn{12}{|c|}{ Forage: Concentrate (F:C) } \\
\hline $40: 60$ & & & 12.44 & 8.23 & 46.86 & 19.14 & 15.50 & 86.43 & 2.46 & 32.16 & 6.01 \\
\hline $60: 40$ & & & 9.09 & 7.37 & 48.45 & 17.93 & 14.50 & 85.66 & 2.72 & 26.96 & 6.09 \\
\hline \multicolumn{12}{|c|}{ Feed additives (FA) } \\
\hline Control & & & 9.57 & 8.35 & 48.79 & 17.98 & 15.28 & 86.94 & 2.72 & 30.57 & 6.07 \\
\hline $\mathrm{NaNO}_{3}$ & & & 8.62 & 7.25 & 46.52 & 19.09 & 14.71 & 85.15 & 2.46 & 29.97 & 6.04 \\
\hline \multicolumn{12}{|l|}{ Oils } \\
\hline Oils-free & & & 11.83 & 8.32 & 50.39 & 17.56 & 15.52 & 88.67 & 2.88 & 31.91 & 6.15 \\
\hline so & & & 8.22 & 7.15 & 45.00 & 19.56 & 14.60 & 83.79 & 2.31 & 27.28 & 5.97 \\
\hline $\mathrm{HO}$ & & & 9.70 & 7.94 & 47.58 & 18.48 & 14.88 & 85.67 & 2.58 & 29.50 & 6.04 \\
\hline S.E.M. & & & 0.306 & 0.149 & 0.481 & 0.207 & 0.155 & 0.429 & 0.54 & 71.559 & 0.015 \\
\hline \multicolumn{12}{|c|}{ Means effects } \\
\hline $\mathrm{F}: \mathrm{C}$ & & & $<0.001$ & $<0.001$ & $<0.001$ & $<0.001$ & $<0.001$ & $<0.001$ & $<0.001$ & $<0.001$ & $<0.001$ \\
\hline FA & & & $<0.001$ & $<0.001$ & $<0.001$ & $<0.001$ & $<0.001$ & $<0.001$ & $<0.001$ & $<0.001$ & 0.006 \\
\hline Oils & & & $<0.001$ & $<0.001$ & $<0.001$ & $<0.001$ & $<0.001$ & $<0.001$ & $<0.001$ & $<0.001$ & $<0.001$ \\
\hline $\mathrm{F}: \mathrm{C} \times \mathrm{FA}$ & & & $<0.001$ & $<0.001$ & $<0.001$ & $<0.001$ & $<0.001$ & $<0.001$ & $<0.001$ & 0.031 & 0.013 \\
\hline
\end{tabular}

a. b. c... The averages shown with different letters in the same column are different from each other.

$\mathrm{CH}_{4}$ : Methane $(\mathrm{ml}) \mathrm{NH}_{3}$ : Ammonia (mg/dl), AA: Acetic acid (mmol/l), PA: Propionic acid (mmol/l), BA: Butiric acid (mmol/l), PP:

Protozoa Population $\left(\times 10^{4} \mathrm{ml}\right), \mathrm{NO}_{3}^{-}$: nitrate, HO: hazelnut oil, SO: soybean oil, S.E.M: Standard error of means 


\begin{tabular}{|c|c|c|c|c|c|c|c|c|c|c|c|}
\hline \multirow{2}{*}{$\begin{array}{l}\text { Forage: } \\
\text { Concentrate }\end{array}$} & \multirow{2}{*}{$\begin{array}{l}\text { Feed } \\
\text { additive }\end{array}$} & \multirow[t]{2}{*}{ Oils } & \multirow[t]{2}{*}{$\mathrm{CH}_{4}$} & \multirow[t]{2}{*}{$\mathrm{NH}_{3}$} & \multicolumn{4}{|l|}{ VFA } & \multirow[t]{2}{*}{ AA:PA } & \multirow[t]{2}{*}{ PP } & \multirow[t]{2}{*}{$\mathrm{pH}$} \\
\hline & & & & & $\mathrm{AA}$ & PA & BA & TVFA & & & \\
\hline $\mathrm{F}: \mathrm{C} \times$ Oils & & & $<0.001$ & 0.008 & $<0.001$ & $<0.001$ & $<0.001$ & $<0.001$ & $<0.001$ & $<0.001$ & 0.033 \\
\hline FA $\times$ Oils & & & 0.015 & 0.004 & $<0.001$ & $<0.001$ & $<0.001$ & $<0.001$ & $<0.001$ & 0.004 & 0.008 \\
\hline $\mathrm{F}: \mathrm{C} \times \mathrm{FA} \times$ Oils & & & $<0.001$ & 0.001 & $<0.001$ & $<0.001$ & $<0.001$ & $<0.001$ & $<0.001$ & 0.017 & 0.015 \\
\hline
\end{tabular}

a. b. c... The averages shown with different letters in the same column are different from each other.

$\mathrm{CH}_{4}$ : Methane $(\mathrm{ml}) \mathrm{NH}_{3}$ : Ammonia (mg/dl), AA: Acetic acid (mmol/l), PA: Propionic acid (mmol/l), BA: Butiric acid (mmol/l), PP:

Protozoa Population $\left(\times 10^{4} \mathrm{ml}\right), \mathrm{NO}_{3}^{-}$: nitrate, HO: hazelnut oil, SO: soybean oil, S.E.M: Standard error of means

\section{2. $\mathrm{NH}_{3}$ concentration in the rumen fluid.}

After 48 hours of incubation, F:C ratio ( $p<0.001), F A(p<0.001), 0(p<0.001), F: C \times F A(p<0.05), F: C$ ratio $\times 0(p<0.05), F A \times 0(p<0.05)$ and F:C ratio $x \mathrm{FA} \times \mathrm{O}(\mathrm{p}<0.05)$ affected $\mathrm{NH}_{3}$ concentration. In the present study, it was found that $\mathrm{NH}_{3}$ concentration $(\mathrm{p}<0.001)$ increased as concentrate level increased. But, in both forage:concentrate ratios, $\mathrm{NO}_{3}^{-}$and $\mathrm{NO}_{3}^{-}+$oil treatment groups led to the lowest concentration of ammonia. Especially $\mathrm{NO}_{3}^{-}+\mathrm{SO}$ treatment group was found to have lowest ammonia concentration. By the way, in both forage: concentrate ratios urea + oils treatments (control group) had higher $\mathrm{NH}_{3}$ concentration.

\section{3. $\mathrm{pH}, \mathrm{VFA}$, and AA: PA ratio}

The $\mathrm{pH}$ values, concentration of total fatty acids (TVFA), AA, PA, BA, and AA:PA ratio were affected by F:C ratio, FA, 0 , and F:C ratio $x$ FA, $\mathrm{F}: \mathrm{C}$ ratio $\times \mathrm{O}, \mathrm{FA} \times \mathrm{O}, \mathrm{F}: \mathrm{C}$ ratio $\times \mathrm{FA} \times \mathrm{O}$ interactions (Table 3). With the high concentrate level in rations (40F:60C), PA, BA, TVFA concentrations were high, whereas with the high forage content (60F:40C), AA, AA:PA ratio and pH were high. By the way, in 40F:60C and 60F:40C, while $\mathrm{NO}_{3}^{-}{ }_{3} \mathrm{NO}_{3}^{-}+$oils increased propionic acid and butyric acid concentration, they decreased acetic acid concentration, TVFA, $\mathrm{AA}: \mathrm{PA}$ ratio, and $\mathrm{pH}$. In the presence of the high concentrate, $\mathrm{NO}_{3}^{-}$and $\mathrm{NO}_{3}^{-}+0$ supplementation increased PA and $\mathrm{BA}$ concentrations $(\mathrm{p}<0.001)$, but decreased AA, TVFA production, AA:PA ratio and $\mathrm{pH}(\mathrm{p}<0.001)$.

\subsection{Protozoa population}

Protozoa number was affected by F:C ratio ( $p<0.001), F A(p<0.001), O(p<0.001), F: C$ ratio $\times F A(p<0.05), F: C$ ratio $\times 0(p<0.001), F A \times 0$ $(p<0.05)$ and F:C ratio $\times$ FA $\times 0$ interaction $(p<0.05)$. Protozoa number was found to be high in the high concentrate level $(40 \mathrm{~F}: 60 \mathrm{C})$ compared to 60F:40C which is high in forage level. At the end of 48 hours of fermentation, in both forage:concentrate ratios $\mathrm{NO}_{3}^{-}$and a combined effect of $\mathrm{NO}_{3}^{-}+\mathrm{O}$ supplementation decreased protozoa population $(\mathrm{p}<0.05)$. In both forage:concentrate ratios, the mitigation effect of $\mathrm{NO}_{3}^{-}+\mathrm{SO}$ supplementation on protozoa number was more evident.

\section{Discussion}

\section{1. $\mathrm{CH}_{4}$ production}

A low $\mathrm{CH}_{4}$ production recorded in high forage level (60F:40C) may be associated with the presence of high levels of secondary metabolites (saponin and condensed tannin) in alfalfa plant used as a roughage source (Kozlowska et al., 2020). Previously, CastroMontoya et al. (2012) found that rations using quillaja plant with high saponin content as a roughage source decreased $\mathrm{CH}_{4}$ production compared to rations with high concentrate feed. Likewise, in some studies, saponin has been found to reduce $\mathrm{CH}_{4}$ production (Morgavi et al., 2012; Jayanegara et al., 2014; Chen et al., 2019). While some researchers found that a low condensed tannin $(C T<0.001 \%)$ content in alfalfa hay decreased $\mathrm{CH}_{4}$ production, some researchers reported a decrease in $\mathrm{CH}_{4}$ production due to the low NDF and a high $\mathrm{CP}$ content and a presence of secondary metabolites in alfalfa (Cheok et al., 2014; Rira et al., 2015; Moate et al., 2017; Szumacher -Strabel et al., 2019). These reports are consistent with our findings.

In current study, the effect of $\mathrm{NO}_{3}^{-}$supplementation on $\mathrm{CH}_{4}$ production in both forage:concentrate ratios was different. In this study the increase of forage level (60F:40C) led to a decrease of $\mathrm{CH}_{4}$ production. An interaction was found between ration type (roughage/concentrate ratio) and $\mathrm{CH}_{4}$ reducing agents (such as nitrate) in cattle (Alvarez-Hess et al., 2019). A high $\mathrm{CH}_{4}$ production found 
in a high concentrate level, is consistent with some studies (Hristov et al., 2015; 2017; Moate et al., 2017; 2019). In this study, a relationship between $\mathrm{CH}_{4}$ production, dietary starch rate and digestion can be established. This is in line with previous findings (HerreraSaldana et al., 1990; McAllister et al., 1996; Alvarez-Hess et al., 2019).

In our study, it was found that $\mathrm{NO}_{3}^{-}+\mathrm{O}$ added rations decreased $\mathrm{CH}_{4}$ production in both forage:concentrate ratios $(\mathrm{p}<0.001)$. Some researchers reported that a combined effect of oils (rich MUFA or PUFA) and $\mathrm{NO}_{3}^{-}$is an effective method to reduce $\mathrm{CH}_{4}$ production in rumen (Leng and Preston, 2010; Yang et al., 2016). It has been determined that a lower effect of $\mathrm{NO}_{3}^{-}$on $\mathrm{CH}_{4}$ production is associated to $\mathrm{NO}_{3}^{-}$and nitrite reducing microorganisms (Guo et al., 2009). Nitrate acts as a hydrogen acceptor. There are studies showing that nitrate has a significant inhibitory effect on $\mathrm{CH}_{4}$ production (El-Zaiat et al., 2014; Olijhoek et al., 2016). Reduction of nitrate to nitrite and then to $\mathrm{NH}_{3}$ reduces $\mathrm{H}$ ions concentration required for the conversion of the $\mathrm{CO}_{2}$ to $\mathrm{CH}_{4}$ compound in the rumen and thus $\mathrm{CH}_{4}$ production decreases (Zhou et al., 2012; Liu et al., 2017). In addition, it has been determined that nitrite has a toxic effect on methanogens (Božic et al., 2009; Zhou et al., 2011). However, the reducing effect of $\mathrm{NO}_{3}^{-}$on $\mathrm{CH}_{4}$ is more evident in rations with a high forage which is rich in condensed tannins or saponins (Pal et al., 2014). This is consistent with our results. In our study, while a high $\mathrm{CH}_{4}$ production was observed in 40F:60C $(12.44 \mathrm{ml})$, a lower $\mathrm{CH}_{4}$ production $(9.09 \mathrm{ml})$ was recorded in low a high forage level (Table 3$)$. This result is related to the increase in saponin and condensed tannins level and their effects on $\mathrm{CH}_{4}$ production in a high forage level.

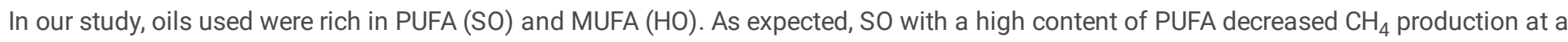
higher level than $\mathrm{HO}$. This finding is consistent with studies reporting that the mitigation effect of fats on $\mathrm{CH}_{4}$ production is related to degree of unsaturation (Rodrigues et al., 2017; Vargas et al., 2017).

In both forage:concentrate ratios the higher negative effect of SO (rich in PUFA) in the reduction of $\mathrm{CH}_{4}$ production (compared to the effect of $\mathrm{HO}$ ) is associated with a high presence of a-linolenic acid (C18:3 cis-9, cis-12, cis-15) and linoleic acid (C18:2 cis-9, cis-12) in SO. Previously, the effect of oils such as flaxseed and rapeseed rich in PUFA on $\mathrm{CH}_{4}$ mitigation was found by some researchers (Chung et al., 2011; Benchaar et al., 2015; Veneman et al., 2015). As a matter of fact, a lowering effect of oils rich in MUFA (oleic acid (C18:1)) on $\mathrm{CH}_{4}$ mitigation was found (Dong et al., 1997). In both forage:concentrate ratios $\mathrm{HO}$ decreased $\mathrm{CH}_{4}$ production. Likewise, in some studies canola oil (22\% linoleic acid, $11 \%$ linolenic acid, and 54\% oleic acid) caused a reduction of $\mathrm{CH}_{4}$ production (Dohme et al., 2000 ; Beauchemin and McGinn, 2015)). It was found that oil (rich in MUFA or PUFA) reduced the cellulolytic bacteria population, methanogenic bacteria, and then $\mathrm{CH}_{4}$ production (Freitas et al., 2018; Nur Atikah et al., 2018).

In present study, the decrease in $\mathrm{CH}_{4}$ production due to $\mathrm{O}$ addition can be associated with the decrease in protozoa population. In both forage:concentrate ratios, it was determined that $\mathrm{NO}_{3}^{-}+\mathrm{O}$ supplementation caused a higher decrease in $\mathrm{CH}_{4}$ production compared to the use of $\mathrm{O}_{\text {and } \mathrm{NO}^{-}}$s separately. This result is consistent with previous studies (Duthie et al., 2017; Villar et al., 2019). Likewise, Guyader et al. (2015) and Veneman et al. (2015) reported that $\mathrm{CH}_{4}$ production decreases when nitrate and flaxseed oil (high in MUFA) are added to ration.

\section{2. $\mathrm{NH}_{3}$ concentration}

In the current study, rumen $\mathrm{NH}_{3}$ values determined for rations used in both forage:concentrate ratios are above the recommended minimum $\mathrm{NH}_{3}$ concentration (4.39 to $7.32 \mathrm{mmol} / \mathrm{I}$ ) (Satter and Slyter, 1974), which is considered sufficient for maximum microbial growth rates. The high $\mathrm{NH}_{3}$ concentration found in the high concentrate level (40F:60C) might be related to the high number of proteolytic bacteria in rumen. Because, proteolytic bacteria increase ruminal $\mathrm{NH}_{3}$ concentration by accelerating protein degradation in rumen.

While this finding is in agreement with some studies (Kljak et al., 2017; Liu et al., 2019), it disagreed with other studies (Jadhav et al., 2017; Liu et al., 2018).

A high forage level (60F:40C) decreased $\mathrm{NH}_{3}$ concentration in present study. This finding can be associated with a high level of alfalfa (rich in saponins), which increased saponin level in ration. Saponin decreased or inhibited $\mathrm{NH}_{3}$ production. Our results were consistent with some previous studies (Belanche et al., 2016; Jadhav et al., 2018).

In our study, the forage:concentrate ratios associated with $\mathrm{NO}_{3}^{-}$supplementation decreased $\mathrm{NH}_{3}(\mathrm{p}<0.001)$. $\mathrm{NO}_{3}^{-}$is converted to nitrite, which has a toxic effect on rumen bacteria, and therefore $\mathrm{NO}_{3}^{-}$addition reduces $\mathrm{NH}_{3}$ concentration at a high level compared to urea 
addition (control group). Nitrate alters the fermentation profile and decreases the $\mathrm{NH}_{3}$ production. However, the conversion rate of $\mathrm{NO}^{-}{ }_{3}$ to $\mathrm{NH}_{3}$ in rumen is slower than urea to $\mathrm{NH}_{3}$.

Various studies investigated the effect of $\mathrm{O}$ (rich in MUFA or PUFA) supplementation on $\mathrm{NH}_{3}$ concentration. While in some studies oil supplementation had no effect (Jalc et al., 2005) on $\mathrm{NH}_{3}$ concentration, in some studies oil supplementation increased (Jalc et al., 2002) or decreased (Szumacher-Strabel et al., 2009; Doreau et al., 2017) $\mathrm{NH}_{3}$ concentration.

In this study, oils rich in PUFA (SO) or in MUFA (HO) associated with the forage:concentrate ratios (40F:60C, and 60F:40C) decreased NH 3 concentration $(p<0.001)$. This can be explained by the presence of linolenic acid (SO) and oleic acid (HO). But the effect of SO (rich in PUFA) was more evident. In fact, the biohydrogenation of linoleic acid consumes more hydrogen (compare to oleic acid). Thus, in our study, the lack of hydrogen causes the decrease in $\mathrm{NH}_{3}$ production. Previously, while Bayat et al. (2017), and Kubelkova et al. (2018) found

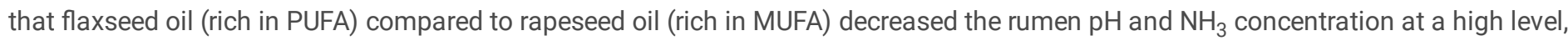
some researchers reported that Moringa oleifera oil rich in MUFA (oleic acid (74.99\%), stearic acid (2.09\%), linolenic acid (1.75\%), and linoleic acid (1.27\%)) increased rumen protected (by-pass) protein and decreased $\mathrm{NH}_{3}$ concentration (Gassenschmidt et al., 1995; Belewu et al., 2014).

In our study, a combined effect of $\mathrm{NO}_{3}^{-}+\mathrm{O}$ supplementation link to the forage:concentrate ratios decreased $\mathrm{NH}_{3}$ concentration ( $\mathrm{p}<0.05$ ). However, combined effect of $\mathrm{NO}_{3}^{-}+\mathrm{SO}$ (compared to $\mathrm{NO}_{3}^{-}+\mathrm{HO}$ ) was more evident on $\mathrm{NH}_{3}$ concentration in the both forage:concentrate ratios. In the same time, the biohydrogenation (due to $\mathrm{O}$ supplementation) and hydrogen sink reaction (due to $\mathrm{NO}^{-}{ }_{3}$ supplementation) $^{-}$ were happened to use the free hydrogen in rumen. Like that, $\mathrm{NH}_{3}$ production decreased because of lack of hydrogen. Previously, combined effect of $\mathrm{NO}_{3}^{-}+\mathrm{O}$ supplementation was reported in some studies (Veneman et al., 2015 ( $\mathrm{NO}_{3}^{-}+$linseed oil supplementation); Villar et al., $2019\left(\mathrm{NO}_{3}^{-}+\right.$canola oil supplementation)).

\section{3. $\mathrm{pH}, \mathrm{VFA}$, and $\mathrm{AA}$ : $\mathrm{PA}$ ratio}

In the present study, $\mathrm{pH}$ values of rations used, are determined from the fluids remaining in the injectors after 48 hours of incubation. The $\mathrm{pH}$ values vary between 5.99 and 6.25 (Table 3). The pH difference in this study is due to forage/concentrate ratio. In this study while a high concentrate level decreased $\mathrm{pH}$, a high forage level increased $\mathrm{pH}$. Although, it was found that $\mathrm{NO}^{-}{ }_{3}$ addition link to forage:concentrate ratios decreased $\mathrm{pH}$ values (p<0.05). This finding is in agreement with some studies (Li et al., 2012; Villar et al., 2019). Likewise, rumen pH

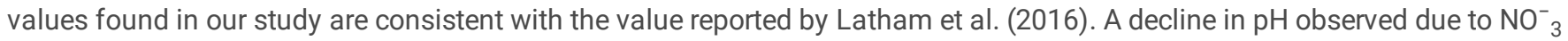
supplementation indicates that microorganisms were not accustomed to digesting nitrate. It suggested that $\mathrm{NO}_{3}^{-}$supplementation caused a dramatic change in rumen conditions. A decreased in $\mathrm{pH}$ due to the high concentrate level can be associated to a high starch content which creates an environment to inhibit nitrate and nitrite metabolism. This means that a high concentrate level provided sufficient energy for the microorganisms to convert nitrate to nitrite and then nitrite to $\mathrm{NH}_{3}$. For this reason, $\mathrm{NH}_{3}$ concentration was high in the high concentrate level (Table 3)

In the present study, oil addition associated to forage:concentrate ratios decreased $\mathrm{pH}$ values. $\mathrm{A}$ decrease in ruminal $\mathrm{pH}, \mathrm{AA}$ concentration, and $\mathrm{CH}_{4}$ production observed due to oil addition in our study can be associated with the degree of unsaturation of oils used (SO and $\mathrm{HO}$ ). Some researchers have reported that oils addition reduces ruminal $\mathrm{pH}, \mathrm{AA}$ concentration, and $\mathrm{CH}_{4}$ production with oils (rich in $\mathrm{MUFA}$ or in PUFA) supplementation (Wu et al., 2016; Majewska et al., 2017; Alvarez-Hess et al., 2019). However, it was found that SO (compared to $\mathrm{HO}$ ) decreased significantly $\mathrm{pH}, \mathrm{AA}$ concentration, and $\mathrm{CH}_{4}$ production (Compared to $\mathrm{HO}$ ). This can be associated to the high level of linolenic acid in SO. This result is consistent with some studies (Russell and Wilson, 1996; Mertens, 1997). By the way, $\mathrm{NO}^{-}{ }_{3}+\mathrm{O}^{-}$ supplementation combine with forage:concentrate ratios decreased more $\mathrm{pH}, \mathrm{AA}$ concentration, and $\mathrm{CH}_{4} \mathrm{production} \mathrm{This}$ is associated to the biohydrogenation of unsaturated fatty acids (PUFA, and MUFA) provided by oil (SO, and HO), and hydrogen sink reaction (due to $\mathrm{NO}^{-}{ }_{3}$ supplementation) which occurred in the same time.

In this experiment, TVFA, individual concentration of VFA (AA, PA, BA, and AA: PA ratio) were affected by $F: C$ ratios, FA, $\mathrm{O}, \mathrm{F}: \mathrm{C}$ ratios $\mathrm{x}$ FA, $\mathrm{F}: \mathrm{C}$ ratios $\times \mathrm{O}, \mathrm{FA} \times \mathrm{O}$.

It was determined that a high concentrate decreased AA concentration, and AA: PP ratio ( $p<0.001)$. An increase in PA, BA, TVFA concentration found in the high concentrate level can be explained by the lowering $\mathrm{pH}$ due to the increase in lactic acid content derived from the high easily fermentable carbohydrates content of rations used, and an increase in carbohydrate fermentation. An increase in BA

Page $11 / 18$ 
concentration can be also associated with the increase in ammonia concentration which inhibited bacterial growth and promotes a fermentation for BA production in this study. As it is known, VFA are produced as a result of microbial fermentation of carbohydrates in the rumen. However, the increase in AA, TVFA, and AA:PA ratio found in the high forage level, is associated with the increase in fiber content (in this case NDF and ADF). Depending on an increase in fibrous content of ration, ruminal hydrogen concentration used in the production of $\mathrm{AA}$ and $\mathrm{CH}_{4}$ increased. Our results are consistent with some studies (Kljak et al., 2017; Moate et al., 2017; Alende et al., 2019).

The increase in PA concentration due to $\mathrm{NO}_{3}^{-}$addition can be explained by the competition between the mechanism of PA production and nitrate (for ammonia production). In other words, propionic acid producing bacteria population (Selenomonas ruminantium, Propionibacterium and Tessaracoccus) increased and they used free $\mathrm{H}$ ions present in the rumen to produce propionic acid. For this reason, hydrogen required for nitrate reduction (nitrite then ammonia) decreased. Consequently, PA concentration increased and $\mathrm{NH}_{3}$ concentration, $\mathrm{AA}$ and AA: PA ratio decreased in the rumen. But, a decrease in $\mathrm{BA}$ (due to $\mathrm{NO}_{3}^{-}$s supplementation) was caused by the rapid reduction of $\mathrm{NO}_{3}^{-}$(to nitrite then ammonia) which use up the electrons needed for the production of BA. However, a high forage level decreased BA concentration. This was due to the combined effect of tannin and $\mathrm{NO}_{3}^{-}$. Our results were consistent with some studies (van Zijderveld et al., 2011; Adejoro and Hassen, 2017; Wang et al., 2018).

In this study, the decrease in $\mathrm{AA}$ due to $\mathrm{NO}_{3}^{-}$supplementation can be explained by the use of free hydrogen for production of $\mathrm{NH}_{3}$ and $\mathrm{PA}$. Like this, hydrogen concentration required for the production of AA decreased. One of the possible reasons for the reduction in the concentration of AA due to the combined effect of $\mathrm{NO}_{3}^{-}$and the two types of oil (MUFA or PUFA) is the use of free hydrogens for the production of PA and BA.

In our study, the effect of $\mathrm{NO}_{3}^{-}+\mathrm{O}$ on VFA and AA: PA ratio changed according to the source of fatty acids (MUFA and PUFA). For that, $\mathrm{NO}_{3}^{-}+\mathrm{SO}$ (rich in PUFA) associated with forage: ratios decreased AA concentration but it increased PA and BA concentrations. This result can be explained by the simultaneous effect of $\mathrm{NO}_{3}^{-}$(hydrogen sinks) and the biohydrogenation of PUFA which consume more free hydrogen than the biohydrogenation of MUFA. A high concentrate level increased more the combined effect of $\mathrm{NO}_{3}^{-}+\mathrm{SO}$ on $\mathrm{AA} \mathrm{CH}_{4}, \mathrm{NH}_{3}$, TVFA and AA:PA ratio. However, while $\mathrm{NO}_{3}^{-}$stimulated the population of propionic acid-producing bacteria, the unsaturated fatty acids (PUFA and MUFA) in $\mathrm{SO}$ and $\mathrm{HO}$ used free hydrogens for biohydrogenation. Thus, the production of $\mathrm{AA}, \mathrm{CH}_{4}, \mathrm{NH}_{3}, \mathrm{TVFA}$ and AA:PA ratio decreased. Our findings are in conformity with those found by Popova et al. (2017) and Villar et al. (2019). Our results showed that AA and $\mathrm{CH}_{4}$ were more decreased due to the combined effect of $\mathrm{NO}_{3}^{-}+\mathrm{SO}$ which can be explained by biohydrogenation of PUFA and $\mathrm{NO}_{3}^{-}$ mechanism (transformation of $\mathrm{NO}_{3}^{-}$to nitrite then to $\mathrm{NH}_{3}$ ) for obtaining PA having different and associative mechanism for using available hydrogen. Use of $\mathrm{NO}_{3}^{-}$and $\mathrm{O}$ in the same time in the ration led to reduction in ruminal hydrogen concentration.

\subsection{Protozoa population (PP)}

In the current study, a high concentrate level increased the number of PP compared to the high forage level $(\mathrm{p}<0.001)$. Previously, it was shown that a high concentrate level can increase (Franzolin and Dehority, 1996; Lengowski et al., 2016) or decrease (Gozho et al., 2005; Khafipour et al., 2009; Hook et al., 2011) protozoa population.

However, the increase in forage (rich in secondary metabolites: saponins and tannins) content of ration link to $\mathrm{NO}_{3}^{-}$addition caused a decrease in the protozoa number. This can be explained by the combine effect of $\mathrm{NO}^{-}{ }_{3}$ and saponins which acted negatively on protozoa population. Our findings are consistent with those of Lin et al. (2013).

In the present study, $\mathrm{NO}_{3}^{-}$added rations associated with forage:concentrate ratios decreased PP. Otherwise, nitrite which come from a transformation of nitrate, inhibits rumen protozoa population and thus $\mathrm{CH}_{4}$ production. This is consistent with findings of Iwamoto et al. (2001).

Furthermore, in our study, there is a parallelism between $\mathrm{NH}_{3}$ concentration and PP in a high forage level, and this finding was reported by some studies (Hu et al., 2005; Liu et al., 2018).

In our study, use of $\mathrm{NO}_{3}^{-}$alone or in combination with $\mathrm{HO}$ (rich in MUFA: oleic acid) and $\mathrm{SO}$ (rich in linolenic acid and linoleic acid) reduced protozoa population. However, the combined effect of $\mathrm{NO}_{3}^{-}+\mathrm{SO}$ decreased protozoa population more than individual use of $\mathrm{NO}_{3}^{-}$and $\mathrm{O}$. This can be explained by the simultaneous mitigation effect of $\mathrm{NO}_{3}^{-}$and PUFA (linolenic acid and linoleic acid) on PP. 
Previously it was demonstrated that $\mathrm{NO}_{3}^{-}$alone (Sar et al., 2005; Asanuma et al., 2015) or in combination with linseed oil (Veneman et al.,

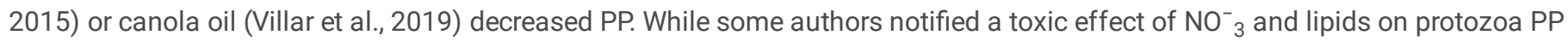
(Morgavi et al., 2010), other researchers reported no significant effect on PP (Guyader et al., 2016).

\section{Conclusion}

In this study, a high forage level (because of a presence of saponins and condansed tannins in high level) decreased $\mathrm{CH}_{4}, \mathrm{AA} \mathrm{NH}_{3}$, $\mathrm{TVFA}$ PP, and AA:PA ratio. While the 60F:40C associated to $\mathrm{NO}_{3}^{-}, \mathrm{O}$ alone or in combination decreased $\mathrm{CH}_{4}, \mathrm{AA}, \mathrm{TVFA}^{\mathrm{P}}$, and $\mathrm{AA}: \mathrm{PA}$ ratio, it increased PA, BA. This study shows that $\mathrm{NO}_{3}^{-}$and $\mathrm{O}(\mathrm{HO}$ and $\mathrm{SO})$ affect $\mathrm{CH}_{4}$ production, protozoa population, $\mathrm{NH}_{3}$ and $\mathrm{VFA}$ concentrations. The combination of $\mathrm{NO}_{3}^{-}$and $\mathrm{O}\left(\mathrm{HO}\right.$ and $\mathrm{SO}$ ) reduced acetic acid, protozoa population (thus $\left.\mathrm{CH}_{4}\right)$, and increased propionic acid and butyric acid more than individual use of nitrate and oils. Our study showed that a combined effect of nitrate and oils can be considered more avantageous to reduce methane production and protozoa population without a negatif effect on PA and BA concentrattions.

The fermentation properties of rations supplemented with nitrate or oils have a potential to improve rumen fermentation. It has been found that the degree of unsaturated fat alone or in combination with $\mathrm{NO}_{3}^{-}$decreases $\mathrm{CH}_{4}$ production and increases VFA.

\section{Declarations}

\section{Funding}

This study was supported by Ondokuz Mayıs University as PYO. ZRT.1904.19.010 Scientific Research Project.

\section{Conflit of interests}

The authors declare that they have no conflict of interest.

\section{Ethics Approval}

Not applicable

\section{Consent to participate}

Not applicable

\section{Consent for publication}

Not applicable

\section{Availability of data and material (data transparency)}

Data on the parameters that were the subject of this study are available from the corresponding author on reasonable request.

\section{Code availability (Software application or custom code)}

Not applicable

\section{Author's contributions}

Euloge O.A. OLOMONCHI and Ali V. GARIPOĞLU conceived and designed the present study. Euloge O.A. OLOMONCHI conducted the literature search, analysed, interpreted data, and drafted the manuscript. The study was supervised by Euloge O.A. OLOMONCHI and Ali V. GARIPOĞLU. All authors read and approved the final manuscript.

\section{References}

1. Adejoro, F. A., and Hassen, A., 2017. Effect of supplementing or treating Eragrostis curvula hay with urea or nitrate on its digestibility and in vitro fermentation. South African Journal of Animal Science, 47(2), 168-177. 
2. Alende, M., Lascano, G. J., Jenkins, T. C., Andrae, J. G., 2019. Contrasting levels of fructose and urea adaded to an annual ryegrass based diet: effects on microbial protein synthesis, nutrient digestibility and fermentation parameters in continuous culture fermenters. Semiárida, 29(1), 33-41.

3. Alvarez-Hess, P. S., Moate, P. J., Williams, S. R. O., Jacobs, J. L., Beauchemin, K. A., Hannah, M. C., ... Eckard, R. J., 2019. Effect of combining wheat grain with nitrate, fat or 3-nitrooxypropanol on in vitro methane production. Animal Feed Science and Technology, 256(11), 42-37.

4. Asanuma, N., Yokoyama, S., Hino, T., 2015. Effects of nitrate addition to a diet on fermentation and microbial populations in the rumen of goats, with special reference to $S$ elenomonas ruminantium having the ability to reduce nitrate and nitrite. Animal Science Journal, 86(4), 378-384.

5. Auffret, M. D., Stewart, R., Dewhurst, R. J., Duthie, C. A., Rooke, J.A., Wallace, R. J., Freeman, T. C., Snelling, T. J., Watson, M., Roehe, R., 2018. Identification, comparison, and validation of robust rumen microbial biomarkers for methane emissions using diverse Bos Taurus breeds and basal diets. Front. Microb, 8(2), 36-42. https://doi.org/10.3389/fmicb.2017.02642.

6. Bayat, A. R., Tapio, I., Vilkki, J., Shingfield, K. J., Leskinen, H., 2017. Plant oilupplements reduce methane emissions and improve milk fatty acid composition in dairy cows fed grass silage-based diets without affecting milk yield. J. Dairy Sci. 101 : 1-16.

7. Beauchemin, K. A., McGinn, S. M., Martinez, T. F., McAllister, T. A., 2007. Use of condensed tannin extract from quebracho trees to reduce methane emissions from cattle. Journal of Animal Science, 85(8), 1990-1996.

8. Beauchemin, K. A., McGinn, S. M. (2015). Methane emissions from feedlot cattle fed barley or corn diets, Journal of Animal Science, 83, 653-661.

9. Benchaar, C., Hassanat, F., Martineau, R., Gervais, R., 2015. Linseed oil supplementation to dairy cows fed diets based on red clover silage or corn silage: Effects on methane production, rumen fermentation, nutrient digestibility, $\mathrm{N}$ balance, and milk production, Journal of Dairy Science, 98, 7993-8008.

10. Belanche, A., Ramos-Morales, E., and Newbold, C. J., 2016. In vitro screening of natural feed additives from crustaceans, diatoms, seaweeds and plant extracts to manipulate rumen fermentation. Journal of the Science of Food and Agriculture, 96(9), 3069-3078.

11. Belewu, M. A., Ahmed, M. A., Badmos, A. H. A., Esan, T. O., Abdulsalam, K. O., Odebisi M. B., and Arise, A. K., 2014. Effect of different levels of moringa oleifera oil on performance characteristics of pregnant goat. Nigerian J. of Agric., Food and Environ., 10(2):29-33.

12. Boadi, D., Benchaar, C., Chiquette, J., Masse, D., 2004. Mitigation strategies to reduce enteric methane emissions from dairy cows: update review, Canadian Journal of Animal Science, 84, 319-335.

13. Bougouin, A., Ferlay, A., Doreau, M., Martin, C., 2018. Effects of carbohydrate type or bicarbonate addition to grass silage-based diets on enteric methane emissions and milk fatty acid composition in dairy cows. Journal of dairy science, 101(7), 6085-6097.

14. Božic, A. K., Anderson, R. C., Carstens, G. E., Ricke, S. C., Callaway, T. R., Yokoyama, M. T., ... \& Nisbet, D. J., 2009. Effects of the methane-inhibitors nitrate, nitroethane, lauric acid, Lauricidin and the Hawaiian marine algae Chaetoceros on ruminal fermentation in vitro. Bioresource technology, 100(17), 4017-4025.

15. Brandt, R. T., Klopfenstein, T. J., 1986a. Evaluation of alfalfa-corn cob associative action. I. Interaction between alfalfa hay and ruminal escape protein on growth of lambs and steers. Journal of Animal Science 63, 894-901.

16. Brandt, R. T., Klopfenstein, T. J., 1986b. Evaluation of alfalfa-corn cob associative action. II. Comparative tests of alfalfa hay as a source of ruminal degradable protein. Journal of Animal Science 63, 902-910.

17. Castro-Montoya, J., De Campeneere, S., Van Ranst, G., \& Fievez, V., 2012. Interactions between methane mitigation additives and basal substrates on in vitro methane and VFA production. Animal Feed Science and Technology, 176(1-4), 47-60.

18. Chen, L., Dong, Z., Li, J., \& Shao, T., 2019. Ensiling characteristics, in vitro rumen fermentation, microbial communities and aerobic stability of low-dry matter silages produced with sweet sorghum and alfalfa mixtures. Journal of the Science of Food and Agriculture, 99(5), 2140-2151.

19. Cheok, C. Y., Salman, H. A. K., Sulaiman, R., 2014. Extraction and quantification of saponins: a review. Food Res. Int. 59, 16-40.

20. Chung, Y. H., He, M. L., McGinn, S. M., McAllister, T. A., Beauchemin, K. A., 2011. Linseed suppresses enteric methane emissions from cattle fed barley silage, but not from those fed grasshay, Animal Feed Science and Technology, 166-167, 321-329.

21. Dong, Y., Bae, H. D., McAllister, T. A., Mathison, G. W., Cheng, K. J., 1997. Lipid-induced depression of methane production and digestibility in the artificial rumen system (RUSITEC), Canadian Journal of Animal Science, 77(2), 269-278.

22. Doreau, M., Arturo-Schaan, M. and Laverroux, S., 2017. Garlic oil reduces ruminal fatty acid biohydrogenation in vitro. European Journal of Lipid Science and Technology, 119(4) 1500388. 
23. Duthie, C. A., Haskell, M. J., Hyslop, J. J., Waterhouse, A., Wallace, R. J., Roehe, R., \& Rooke, J. A., 2017. The impact of divergent breed types and diets on methane emissions, rumen characteristics and performance of finishing beef cattle. Animal, 11(10), 1762-1771.

24. El-Zaiat, H. M., Araujo, R. C., Soltan, Y. A., Morsy, A. S., Louvandini, H., Pires, A. V., ... \& Abdalla, A. L., 2014. Encapsulated nitrate and cashew nut shell liquid on blood and rumen constituents, methane emission, and growth performance of lambs. Journal of animal science, 92(5), 2214-2224.

25. Franzolin, R., Dehority, B. A., 1996. Effect of prolonged high-concentrate feeding on ruminal protozoa concentrations. Journal of animal science, 74(11), 2803-2809.

26. Freitas, D. S., Terry, S. A., Ribeiro, R. S., Pereira, L. G. R., Tomich, T. R., Machado, F. S., Campos, M. M., Corrêa, P. S., Abdalla, A. L., Maurício, R. M., Chaves, A. V., 2018. Unconventional vegetable oils for a reduction of methanogenesis and modulation of ruminal fermentation. Front. Vet. Sci. 5:201. doi:10.3389/fvets.2018.00201.

27. Gassenschmidt, U., Jany, K. D., Tauscher, B., and Niebergall, H., 1995. Isolation and characterization of a flocculating protein from Moringa oleifera Lam. Biochimica Biophysica Acta, 1243: 477 - 481.

28. Goel, G., Makkar, H. P. S., Becker, K., 2008. Changes in microbial community structure, methanogenesis and rumen fermentation in response to saponin-rich fractions from different plant materials. Journal of Applied Microbiology, 105(3), $770-777$.

29. Gozho, G. N., Plaizier, J. C., Krause, D. O., Kennedy, A. D., \& Wittenberg, K. M., 2005. Subacute ruminal acidosis induces ruminal lipopolysaccharide endotoxin release and triggers an inflammatory response. Journal of Dairy Science, 88(4), 1399-1403. https://doi.org/10.3168/jds.S0022-0302(05)72807-1.

30. Guo, W. S., Schaefer, D. M., Guo, X. X., Ren, L. P., Meng, Q. X., 2009. Use of nitrate-nitrogen as a sole dietary nitrogen source to inhibit ruminal methanogenesis and to improve microbial nitrogen synthesis in vitro, Asian-Australasian Journal of Animal Sciences, 22(4), 542-549.

31. Guyader, J., Eugène, M., Meunier, B., Doreau, M., Morgavi, D. P., Silberberg, M., ... \& Martin, C., 2015. Additive methane-mitigating effect between linseed oil and nitrate fed to cattle, Journal of Animal Science, 93(7), 3564-3577.

32. Guyader, J., Janzen, H. H., Kroebel, R., Beauchemin, K. A., 2016. Forage use to improve environmental sustainability of ruminant production, Journal of animal science, 94(8), 3147-3158.

33. Herrera-Saldana, R. E., Huber, J. T., Poore, M. H., 1990. Dry matter, crude protein, andstarch degradability of five cereal grains1. J Dairy Sci. 73: 2386-93. doi:10.3168/jds.S0022-0302(90)78922-9

34. Hook, S. E., Steele, M. A., Northwood, K. S., Dijkstra, J., France, J., Wright, A. D., \& McBride, B. W., 2011. Impact of subacute ruminal acidosis (SARA) adaptation and recovery on the density and diversity of bacteria in the rumen of dairy cows. FEMS Microbiology Ecology, 78(2), 275-284. https://doi.org/10.1111/j.1574-6941.2011.01154.x

35. Hristov, A. N., Oh, J., Firkins, J. L., Dijkstra, J., Kebreab, E., Waghorn, G., ... \& Gerber, P. J., 2013. Special topics Mitigation of methane and nitrous oxide emissions from animal operations: I. A review of enteric methane mitigation options. Journal of animal science, 91(11), 5045-5069.

36. Hristov, A. N., Oh, J., Giallongo, F., Frederick, T. W., Harper, M. T., Weeks, H. L., ... \& Kindermann, M., 2015. An inhibitor persistently decreased enteric methane emission from dairy cows with no negative effect on milk production. Proceedings of the National Academy of Sciences, 112(34), 10663-10668.

37. Hristov, A. N., Harper, M., Meinen, R., Day, R., Lopes, J., Ott, T., ... \& Randles, C. A., 2017. Discrepancies and uncertainties in bottom-up gridded inventories of livestock methane emissions for the contiguous United States. Environmental science \& technology, 51(23), 13668-13677.

38. Hu, W., Liu, J., Ye, J., Wu, Y., Guo, Y., 2005. Effect of tea saponin on rumen fermentation in vitro. Anim. Feed Sci. Technol. $120,333-339$.

39. Hunt, C.W., Paterson, J. A., Williams, J. E., 1985. Intake and digestibility of alfalfa-tall fescue combination diets fed to lambs. Journal of Animal Science 60, 301-312.

40. IPCC, Field, C. B. (Ed.)., 2014. Climate change 2014-Impacts, adaptation and vulnerability: Regional aspects. Cambridge University Press.

41. Iwamoto, M., Asanuma, N., Hino, T., 2001. Effects of $\mathrm{pH}$ and electron donors on nitrate and nitrite reduction in ruminal microbiota. Nihon Chikusan Gakkaiho, 72(2), 117-125.

42. Jadhav, R. V., Kannan, A., Bhar, R., Sharma, O. P., Bhat, T. K., Gulati, A., ... \& Sharma, V. K., 2017. Effect of tea (Camellia sinensis) seed saponin supplementation on growth performance, nutrient utilization, microbial protein synthesis and hemato-biochemical attributes of Gaddi Goats. Animal Nutrition and Feed Technology, 17(2), 255-268. 
43. Jadhav, R. V., Kannan, A., Bhar, R., Sharma, O. P., Gulati, A., Rajkumar, K., ... \& Verma, M. R., 2018. Effect of tea (Camellia sinensis) seed saponins on in vitro rumen fermentation, methane production and true digestibility at different forage to concentrate ratios. Journal of Applied Animal Research, 46(1), 118-124.

44. Jalč, D., Kišidayová, S., \& Nerud, F., 2002. Effect of plant oils and organic acids on rumen fermentation in vitro. Folia microbiologica, 47(2), 171-177.

45. Jalč, D., \& Čertík, M., 2005. Effect of microbial oil, monensin and fumarate on rumen fermentation in artificial rumen. Czech J. Anim. Sci, 50(10), 467-472.

46. Jayanegara, A., Wina, E., \& Takahashi, J., 2014. Meta-analysis on methane mitigating properties of saponin-rich sources in the rumen: influence of addition levels and plant sources. Asian-Australasian journal of animal sciences, 27(10), 1426.

47. KanthaRaju, M., Jagadeeswary, V., Satyanarayan, K., Veeranna, K., Rajeshwari, Y., Nagaraj, C., Shilpa Shree, J., 2018. Intensive Cultivation of Medicago sativa for Sustainable Milk Production an Action Oriented Approach. International Journal of Livestock Research, 8(4), 101-108.

48. Khafipour, E., Krause, D. O., \& Plaizier, J. C., 2009. Alfalfa pellet-induced subacute ruminal acidosis in dairy cows increases bacterial endotoxin in the rumen without causing inflammation. Journal of Dairy Science, 92(4), 1712-1724.

49. Kljak, K., Pino, F., Heinrichs, A. J., 2017. Effect of forage to concentrate ratio with sorghum silage as a source of forage on rumen fermentation, N balance, and pürine derivative excretion in limit-fed dairy heifers. J. Dairy Sci. 100: 213-223.

50. Koukoura, Z., Kykriazopoulos, A. P., \& Parissi, Z. M., 2009. Growth characteristics and nutrient content of some herbaceous species under shade and fertilization. Spanish Journal of Agricultural Research, (2), 431-438.

51. Kozlowska, M., Cieślak, A., Jóźwik, A., El-Sherbiny, M., Stochmal, A., Oleszek, W., ... \& Szumacher-Strabel, M., 2020. The effect of total and individual alfalfa saponins on rumen methane production. Journal of the Science of Food and Agriculture, 100(5), 1922-1930.

52. Kuchenmeister, K., Kuchenmeister, F., Kayser, M., WRAGE, M. N., \& Isselstein, J. (2013). Influence of drought stress on nutritive value of perennial forage legumes. Int. J., Plant Prod., 7(4): 693-710.

53. Kubelková, P., Jalč, D., Jančík, F., Homolka, P., 2018. In vitro ruminal fermentation and fatty acid production by various oil seeds. South African Journal of Animal Science, 48(3), 526. doi:10.4314/sajas. v48i3.13.

54. Kubkomawa, I. H., Ogundu, M. A., Okoli, I. C., \& Udedibie, A. B. I., 2017. Biochemical profiling of the values of dry season feed resources in pastoralcattle environment in Nigeria. International Journal of Research in Agriculture and Forestry, 4(4), 23-36.

55. Latham, E. A., Anderson, R. C., Pinchak, W. E., \& Nisbet, D. J., 2016. Insights on alterations to the rumen ecosystem by nitrate and nitrocompounds. Frontiers in microbiology, 7, 228.

56. Leng, R. A., 1990. Factors affecting the utilization of 'poor-quality' forages by ruminants particularly under tropical conditions. Nutrition Research Reviews 3, 277-303.

57. Leng, R. A., \& Preston, T. R., 2010. Further considerations of the potential of nitrate as a high affinity electron acceptor to lower enteric methane production in ruminants. Livestock Research for Rural Development, 22 (221).

58. Lengowski, M. B., Zuber, K. H., Witzig, M., Mohring, J., Boguhn, J., \& Rodehutscord, M., 2016. Changes in rumen microbial community composition during adaption to an in vitro system and the im pact of different forages. PLoS One, 11(2), e0150115.

59. Li, L., Davis, J., Nolan, J., \& Hegarty, R., 2012. An initial investigation on rumen fermentation pattern and methane emission of sheep offered diets containing urea or nitrate as the nitrogen source. Animal Production Science, 52(7), 653-658

60. Lin, M., Schaefer, D. M., Zhao, G. Q., \& Meng, Q. X., 2013. Effects of nitrate adaptation by rumen inocula donors and substrate fiber proportion on in vitro nitrate disappearance, methanogenesis, and rumen fermentation acid. Animal: an international journal of animal bioscience, 7(7), 1099.

61. Liu, K. H., Niu, Y., Konishi, M., Wu, Y., Du, H., Chung, H. S., ... Ishida, T., 2017. Discovery of nitrate CPK NLP signalling in central nutrientgrowth networks, Nature, 545(7654), 311.

62. Liu, C., Qu, Y. H., Guo, P. T., Xu, C. C., Ma, Y., Luo, H. L., 2018. Effects of dietary supplementation with alfalfa (Medicago sativa L.) on lamb growth performance, nutrient digestibility, and plasma parameters. Animal Feed Science and Technology 236 (2018) $98-106$.

63. Liu, X., Xu, Q., Wang, D., Wu, Y., Yang, Q., Liu, Y., ... \& Yang, G., 2019. Unveiling the mechanisms of how cationic polyacrylamide affects short-chain fatty acids accumulation during long-term anaerobic fermentation of waste activated sludge. Water research, $55,142-151$.

64. Lloyd, Hillman, K., Yarlett, A., Williams, A.G. Hydrogen Production by Rumen Holotrich Protozoa: Effects of Oxygen and Implications for Metabolic Control by In Situ Conditions. The Journal of Protozoology,36, 2, 205-213.

65. Majewska, M.P., Miltko, R., Bełżecki, G., Skomiał, J., Kowalik, B., 2017. Supplementation of rapeseed and linseed oils to sheep rations: effects on ruminal fermentation characteristics and protozoal populations. Czech J. Anim. Sci., 62, 527-538.

Page 16/18 
66. Martin, C., Morgavi, D., \& Doreau, M., 2010. Methane mitigation in ruminants: from microbe to the farm scale. Animal, 4(3), $351-365$.

67. Mertens, D. R., 1997. Creating a system for meeting the fiber requirements of dairy cows. Journal of dairy science, 80(7), $1463-1481$.

68. McAllister, T. A., Cheng, K. J., Okine, E. K., \& Mathison, G. W., 1996. Dietary, environmental and microbiological aspects of methane production in ruminants. Canadian Journal of Animal Science, 76(2), 231-243.

69. McGinn, S. M., Bodas, K. A., Coates, T., Colombatto, D., 2004. Methane emissions from beef cattle: Effects of monensin, sunflower oil, enzymes, yeast, and fumaric acid, Journal of animal science, 82(11), 3346-3356.

70. Moate, P. J., Williams, S. R. O., Jacobs, J. L., Hannah, M. C., Beauchemin, K. A., Eckard, R. J., \& Wales, W. J., 2017. Wheat is more potent than corn or barley for dietary mitigation of enteric methane emissions from dairy cows. Journal of Dairy Science, 100(9), $7139-7153$.

71. Moate, P. J., Williams, S. R. O., Deighton, M. H., Hannah, M. C., Ribaux, B. E., Morris, G. L., ... \& Wales, W. J., 2019. Effects of feeding wheat or corn and of rumen fistulation on milk production and methane emissions of dairy cows. Animal Production Science, 59(5), 891-905.

72. Morgavi, D. P., Martin, C., Jouany, J. P., and Ranilla, M. J., 2012. Rumen protozoa and methanogenesis: not a simple cause effect relationship. The British Journal of Nutrition 107, 388-397.

73. Muir, J. P., Ocumpaugh, W. R, Read, J. C., 2003. Spring forage yield and nutritive value of Texas black medic accessions. Agron. J., 95 (4): 908-912.

74. Nur Atikah, I., Alimon, A. R., Yaakub, H., Abdullah, N., Jahromi, M. F., Ivan, M., Samsudin, A. A., 2018. Profiling of rumen fermentation, microbial population and digestibility in goats fed with dietary oils containing different fatty acids. BMC Veterinary Research, $14: 344$.

75. Olijhoek, D. W., Hellwing, A. L. F., Brask, M., Weisbjerg, M. R., Højberg, O., Larsen, M. K., Lund P., 2016. Effect of dietary nitrate level on enteric methane production, hydrogen emission, rumen fermentation, and nutrient digestibility in dairy cows. Journal of Dairy Science, 99(8), 6191-6205.

76. Ørskov, E. R., Liu, J. X., Chen, X. B., 1999. Optimization of steam treatment as a method for upgrading rice straw as feeds. Animal Feed Science and Technology 76, 345-357.

77. Pal, K., Patra, A. K., Sahoo, A., \& Mandal, G. P., 2014. Effect of nitrate and fumarate in Prosopis cineraria and Ailanthus excelsa leavesbased diets on methane production and rumen fermentation. Small Ruminant Research, 121(2-3), 168-174.

78. Paterson, J. A., Klopfenstein, T. J., Britton, R. A., 1982. Digestibility of sodium hydroxide-treated crop residues when fed with alfalfa hay. Journal of Animal Science 54, 1056-1066.

79. Popova, M., Guyader, J., Silberberg, M., Seradj, A. R., Saro, C., Bernard, A., ... \& Morgavi, D. P. (2019). Changes in the rumen microbiota of cows in response to dietary supplementation with nitrate, linseed, and saponin alone or in combination. Applied and environmental microbiology, 85(4).

80. Ranilla, M. J., Carro, M. D., Valdés, C., Giráldez, F. J., \& López, S., 1997. A comparative study of ruminal activity in Churra and Merino sheep offered alfalfa hay. Animal Science, 65(1), 121-128.

81. Rira, M., Chentli, A., Boufenera, S., Bousseboua, H., 2015. Effects of plants containing secondary metabolites on ruminal methanogenesis of Sheep in vitro. Energy Procedia 74, 15-24.

82. Rodrigues, J. P. P., Ramin, M., Huhtanen, P., Aru, F., Detmann, E., Marcondes, M. I., 2017. Effect of soyabean oil supplementation and forage type on methane production and fibre digestibility using the in vitro gas production system, Grass Forage Sci, 00: 1-13.

83. Russell, J. B., \& Wilson, D. B., 1996. Why are ruminal cellulolytic bacteria unable to digest cellulose at low pH? Journal of dairy science, 79(8), 1503-1509.

84. Sar, C., Mwenya, B., Pen, B., Takaura, K., Morikawa, R., Tsujimoto, A., Kuwaki, K., Isogai, N.,jShinzato, I., Asakura, Y., Toride, Y., Takahashi, J., 2005. Effect of ruminal administration of Escherichia coli wild type or a genetically modifi ed strain with enhanced high nitrite reductase activity on methane emission and nitrate toxicity in nitrate-infused sheep, Br. J. Nutr. 94:691-697.

85. Satter, L. D., Slyter, L. L., 1974. Effect of ammonia concentration on rumen microbial proteinproduction in vitro, Brit. J. Nutr, 32:199208.

86. Sharifi, M., Taghizadeh, A., Khadem, A. A., Hosseinkhani, A., Mohammadzadeh, H., 2018. Effects of nitrate supplementation and forage level on gas production, nitrogen balance and dry-matter degradation in sheep, Animal Production Science. Animal Production Science, 59(3), 515-523.

87. Szumacher-Strabel, M., Cieslak, A., Nowakowska, A., 2009. Effect of oils rich in linoleic acid on in vitro rumen fermentation parameters of sheep, goats and dairy cows, J. Anim. Feed Sci, 18(3), 440-452

88. Szumacher-Strabel, M., Stochmal, A., Cieslak, A., Kozłowska, M., Kuznicki, D., Kowalczyk, M., \& Oleszek, W., 2019. Structural and quantitative changes of saponins in fresh alfalfa compared to alfalfa silage. Journal of the Science of Food and Agriculture, 99(5),

Page $17 / 18$ 
2243-2250.

89. Ungerfeld, E. M., \& Kohn, R. A., 2006. The role of thermodynamics in the control of ruminal fermentation. Ruminant physiology: digestion, metabolism and impact of nutrition on gene expression, immunology and stress, 55-85.

90. Van Zijderveld, S. M., Gerrits, W. J. J., Dijkstra, J., Newbold, J. R., Hulshof, R. B. A., \& Perdok, H. B., 2011. Persistency of methane mitigation by dietary nitrate supplementation in dairy cows. Journal of Dairy Science, 94(8), 4028-4038.

91. Vargas, J. E., Andrés, S., Snelling, T. J., López-Ferreras, L., Yáñez-Ruíz, D. R., García-Estrada, C., \& López, S., 2017. Effect of sunflower and marine oils on ruminal microbiota, in vitro fermentation and digesta fatty acid profile. Frontiers in microbiology, 8, 1124.

92. Veneman, J. B., Muetzel, S., Hart, K. J., Faulkner, C. L., Moorby, J. M., Perdok, H. B., \& Newbold, C. J., 2015. Does dietary mitigation of enteric methane production affect rumen function and animal productivity in dairy cows? PloS one, 10(10), e0140282.

93. Villar, M. L., Hegarty, R. S., Nolan, J. V., Godwin, I. R., \& McPhee, M., 2019. The effect of dietary nitrate and canola oil alone or in combination on fermentation, digesta kinetics and methane emissions from cattle. Animal Feed Science and Technology, 259, 114294.

94. Wang, R., Wang, M., Ungerfeld, E. M., Zhang, X. M., Long, D. L., Mao, H. X., ... \& Tan, Z. L., 2018. Nitrate improves ammonia incorporation into rumen microbial protein in lactating dairy cows fed a low-protein diet. Journal of dairy science, 101(11), $9789-9799$.

95. Wu, D., Xu, L., Tang, S., Guan, L., He, Z., Guan, Y., ... \& Wang, M., 2016. Influence of oleic acid on rumen fermentation and fatty acid formation in vitro. PLoS One, 11(6), e0156835.

96. Yang, C., Rooke, J. A., Cabeza, I., and Wallace, R. J., 2016. Nitrate and inhibition of ruminal methanogenesis: Microbial ecology, obstacles, and opportunities for lowering methane emissions from ruminant livestock. Front. Microbiol. 7:132. doi:

$10.3389 /$ fmicb.2016.00132

97. Yang, K., Wei, C., Zhao, G. Y., Xu, Z. W., \& Lin, S. X., 2017. Effects of dietary supplementing tannic acid in the ration of beef cattle on rumen fermentation, methane emission, microbial flora and nutrient digestibility. Journal of animal physiology and animal nutrition, 101(2), 302-310.

98. Zhou, Z., Meng, Q., Yu, Z., 2011. Effects of methanogenic inhibitors on methane production and abundance of methanogen and cellulolytic bacteria in in-vitro ruminal cultures. Appl. Environ. Microbiol. 77, 2634-2639.

99. Zhou, Z., Yu, Z., \& Meng, Q., 2012. Effects of nitrate on methane production, fermentation, and microbial populations in in vitro ruminal cultures. Bioresource Technology, 103(1), 173-179. 